\title{
LAHAN MENJADI FAKTOR PENGHAMBAT DALAM PELAKSANAAN PEMBANGUNAN UNTUK KEPENTINGAN UMUM
}

\author{
Bambang Istijono ${ }^{1}$
}

\begin{abstract}
ABSTRAK
Terdapat beberapa resiko yang berpotensi menjadi penghambat pekerjaan konstruksi, selain masalah kinerja kontraktor, kinerja konsultan, koordinasi dengan pihak terkait. Salah satunya adalah masalah pengadaan lahan/pembebasan tanah. Masalah pembebasan tanah tidak hanya terjadi di perkotaan tetapi juga terjadi di daerah, terutama yang masih mengenal tanah ulayat/adat. Permasalahan lahan menjadi faktor penting untuk diselesaikan sebelum dimulainya suatu pekerjaan konstruksi, tanah yang belum bebas akan dapat menghambat pelaksanaan pekerjaan, bahkan menyebabkan pekerjaan tidak dapat diselesaikan sesuai jadwal kontrak. Tulisan ini menguraikan tentang teori pengadaan tanah, peraturan tentang pengadaan tanah dalam pelaksanaan pembangunan untuk kepentingan umum dan beberapa kasus terjadi di pekerjaan jembatan, jalan dan pekerjaan irigasi, dengan mengidentifikasi faktor yang menjadi penghambat pembebasan lahan. Hasil penelitian menunjukkan bahwa permasalahan pembebasan lahan terjadi karena terdapat perbedaan patokan nilai harga ganti rugi antara pemilik tanah dan Pemerintah. Disarankan bahwa harga patokan tanah tidak hanya berpedoman pada harga saat ini, tetapi juga memperhitungkan harga jual tanah pada saat proyek selesai dilaksanakan.
\end{abstract}

Kata kunci : pengadaan lahan, pembangunan, kepentingan umum

\section{PENDAHULUAN}

Infrastruktur bidang pekerjaan umum berfungsi mendukung perkembangan dan pertumbuhan ekonomi, sosial dan budaya, dimana penyediaan infrastruktur bidang pekerjaan umum harus melalui proses penyelenggaraan pekerjaan konstruksi yang meliputi tahap perencanaan, penyediaan lahan yang akan terkena tapak bangunan, pelaksanaan konstruksi, operasi dan pemeliharaan. Penyediaan lahan merupakan faktor penentu untuk kelancaran pembangunan dan hampir tidak ada kegiatan pembangunan yang tidak memerlukan lahan. Lahan tanah yang digunakan dapat berupa tanah yang dikuasai negara atau tanah yang dimiliki dengan suatu hak oleh suatu obyek hukum yang dapat berupa hak milik, hak guna usaha, hak guna bangunan atau hak pakai. Tantangan yang dihadapi oleh pelaksana pembangunan di daerah, selain masalah kinerja kontraktor, kinerja konsultan, koordinasi dengan pihak terkait yang berhubungan dengan kelancaran suatu pekerjaan adalah masalah penyediaan lahan tanah yang terkena tapak bangunan. Sebagai contoh pembangunan bendung dan saluran irigasi di Sawah Laweh Tarusan untuk mengairi sawah lebih dari 3.200 hektar di Kabupaten Pesisir Selatan, selama 8 bulan sejak kontrak ${ }^{1)}$ ditanda tangani oleh Pejabat Pembuat Komitmen Kementerian Pekerjaan Umum dengan Kontraktor PT. Adhi Karya belum dapat dimulai pelaksanaanya karena lahan belum bebas. Pemerintah telah menerbitkan peraturan tentang penyelenggaraan pengadaan tanah dalam pembangunan untuk kepentingan

\footnotetext{
${ }^{1}$ Staf Pengajar Jurusan Teknik Sipil Fakultas Teknik Universitas Andalas, bistijono1452@yahoo.co.id
} 
umum, yang bertujuan untuk menghindari konflik yang terjadi sehingga pekerjaan pembangunan dapat berjalan lancar. Dalam pelaksanaannya masih ditemui banyak kendala atau hambatan pekerjaan pembangunan di lapangan. Berdasarkan hal tersebut di atas, penelitian ini bertujuan untuk menganalisa permasalahan pengaadan lahan untuk pekerjaan konstruksi untuk kepentingan umum.

\section{METODOLOGI}

Pelaksanaan penelitian ini didasari oleh peraturan perundang-undangan penyediaan lahan pembangunan untuk kepentingan umum, melakukan wawancara dengan pemangku kepentingan dan masyarakat terkait dengan permasalahan dalam pembebasan lahan. Untuk itu, dianalisa empat kasus proyek yang terkendala pelaksanannya akibat tidak selesainya pembebasan lahan, yaitu pembangunan Jembatan Kuranji-Durian Tarung di Kota Padang, pembangunan bendung dan saluran irigasi Sawah Laweh Tarusan di Kabupaten Pesisir Selatan, pembangunan Saluran Irigasi Batang Anai di Kabupaten Padang Pariaman dan Kota Pariaman, dan pembangunan Peningkatan Jalan Masuk ke Tempat Pembuangan Akhir Sampah di Kota Payakumbuh.

\section{TINJAUAN PUSTAKA}

\subsection{Kepentingan Umum}

Dalam Keputusan Presiden No. 55 tahun 1993 tentang Pengadaan tanah bagi pelaksanaan pembangunan untuk kepentingan umum, kepentingan umum dirumuskan sebagai pembangunan oleh Pemerintah untuk kepentingan seluruh lapisan masyarakat serta tidak digunakan untuk mencari keuntungan, dapat berupa antara lain :

a. Jalan umum, saluran pembuangan air ;

b. Bendungan, bendung, saluran irigasi ;

c. Rumah sakit umum dan pusat-pusat kesehatan masyarakat ;

d. Pelabuhan, bandar udara, terminal ;

e. Rumah peribadatan ;

f. Prasarana pendidikan, sekolahan ;

g. Kantor Pemerintah ;

h. Fasilitas keselamatan umum ;

i. Fasilitas Angkatan Bersenjata Republik Indonesia.

Sedangkan dalam Undang-undang No. 2 tahun 2012 tentang Pengadaan tanah bagi pembangunan untuk kepentingan umum dan Peraturan Presiden No. 71 tahun 2012 tentang Penyelenggaraan pengadaan tanah dalam pembangunan untuk kepentingan umum, definisi kepentingan umum adalah kepentingan bangsa, negara dan masyarakat yang harus diwujudkan oleh Pemerintah dan digunakan sebesar-besarnya untuk kemakmuran rakyat.

\subsection{Pengadaan Lahan Tanah ${ }^{2)}$}

Pembangunan berbagai fasilitas untuk kepentingan umum memerlukan bidang tanah yang cukup dan untuk itu pengadaannya perlu dilakukan dengan sebaik-baiknya. Pengadaan dan rencana pemenuhan kebutuhan tanah yang diperlukan bagi pelaksanaan pembangunan untuk kepentingan umum hanya dapat dilakukan apabila penetapan rencana pembangunan tersebut sesuai dan berdasarkan Rencana Umum Tata Ruang dan prioritas pada rencana pembangunan daerah. 
Pelepasan atau penyerahan hak atas tanah bagi pelaksanaan pembangunan untuk kepentingan umum oleh Pemerintah dilakukan berdasarkan prinsip penghormatan terhadap hak atas tanah dan pengadaan tanahnya dilakukan melalui musyawarah.

Beberapa tahapan dalam pengadaan $\operatorname{tanah}^{3)}$ yaitu :

a. Instansi Pemerintah yang memerlukan lahan tanah melakukan perencanaan dan mengajukan permintaan penetapan lokasi pembangunan untuk kepentingan umum kepada Gubernur.

b. Panitia yang ditunjuk Gubernur bersama instansi Pemerintah yang memerlukan tanah memberikan penyuluhan kepada masyarakat yang terkena tapak pembangunan, mengenai maksud dan tujuan pembangunan, termasuk penjelasan luasan bidang datar (horisontal) lahan tanah.

c. Panitia melakukan kegiatan inventarisasi mengenai bidang-bidang tanah, termasuk bangunan, tanaman dan/atau benda-benda lain yang terkait dengan tanah yang bersangkutan, selanjutnya diumumkan hasil inventarisasinya.

d. Panitia melaksanakan musyawarah dengan pemegang hak atas tanah dan pemilik bangunan, tanaman dan/atau benda-benda lain yang terkait dengan tanah yang bersangkutan dalam rangka menetapkan bentuk dan besarnya ganti kerugian yang layak dan adil, dengan mempertimbangkan nilai tanah berdasarkan nilai nyata/apraisal dan Nilai Jual Obyek Pajak Bumi dan Bangunan (NJOP).

\subsection{Asas Hukum dalam Pengadaan Tanah untuk Kepentingan Umum ${ }^{3)}$}

Penyediaan tanah untuk kepentingan umum diatur dalam peraturan perundang-undangan yang substansinya didasarkan asas hukum, sebagai berikut :

a. Asas Kemanusiaan, pengadaan tanah harus memberikan perlindungan serta penghormatan terhadap hak asasi manusia, harkat dan martabat setiap warga negara dan penduduk Indonesia secara proposional.

b. Asas Keadilan, memberikan jaminan penggantian yang layak kepada pihak yang berhak dalam proses pengadaan tanah sehingga mendapatkan kesempatan untuk dapat melangsungkan kehidupan yang lebih baik.

c. Asas Kemanfaatan, hasil pengadaan tanah mampu memberikan manfaat secara luas bagi kepentingan masyarakat, bangsa dan negara.

d. Asas Kepastian, memberikan kepastian hukum tersedianya tanah dalam proses pengadaan tanah untuk pembangunan dan memberikan jaminan kepada pihak yang berhak untuk mendapatkan ganti kerugian yang layak.

e. Asas Keterbukaan, pengadaan tanah untuk pembangunan dilaksanakan dengan memberikan akses kepada masyarakat untuk mendapatkan informasi yang berkaitan dengan pengadaan tanah.

f. Asas Kesepakatan, proses pengadaan tanah dilakukan dengan musyawarah para pihak tanpa unsur paksaan untuk mendapatkan kesepakatan bersama.

g. Asas Keikutsertaan, dukungan dalam penyelenggaraan pengadaan tanah melalui partisipasi masyarakat, baik secara langsung, sejak perencanaan sampai dengan kegiatan pembangunan.

h. Asas Kesejahteraan, pengadaan tanah untuk pembangunan dapat memberikan nilai tambah bagi kelangsungan kehidupan pihak yang berhak dan masyarakat secara luas.

i. Asas Keberlanjutan, kegiatan pembangunan dapat berlangsung secara terus menerus, berkesinambungan untuk mencapai tujuan yang diharapkan.

j. Asas Keselarasan, pembangunan tanah untuk pembangunan dapat seimbang dan sejalan dengan kepentingan masyarakat dan negara. 


\section{TINJAUAN PUSTAKA}

\subsection{Pembangunan Jembatan Kuranji-Durian Tarung di Kota Padang}

a. Kelurahan Kuranji dan Kelurahan Pasar Ambacang dipisahkan oleh Batang Kuranji, saat ini akses bagi masyarakat dikedua kelurahan tersebut melalui jalan Padang Bypass yang padat atau melalui jembatan pemeliharaan Bendung Gunung Nago yang sempit. Memperhatikan kondisi ini sesuai tata ruang kota dan prioritas pembangunan daerah, Pemerintah Kota membangun jembatan diatas Batang Kuranji untuk menghubungkan kedua kelurahan dengan dana APBD Propinsi Sumatera Barat, dengan rencana manfaat untuk memperpendek waktu tempuh dan mengurangi kepadatan jalan, serta membuka daerah perekonomian baru bagi masyarakat.

b. Data teknis jembatan. Jembatan kelas A, panjang jembatan 160 meter terdiri dari 2 x 30 meter jembatan balok girder beton dan ditengah sepanjang 100 meter dari rangka baja, dengan lebar jembatan 8 meter. Konstruksi pondasi langsung dengan box coison (Gambar 1 dan 2).

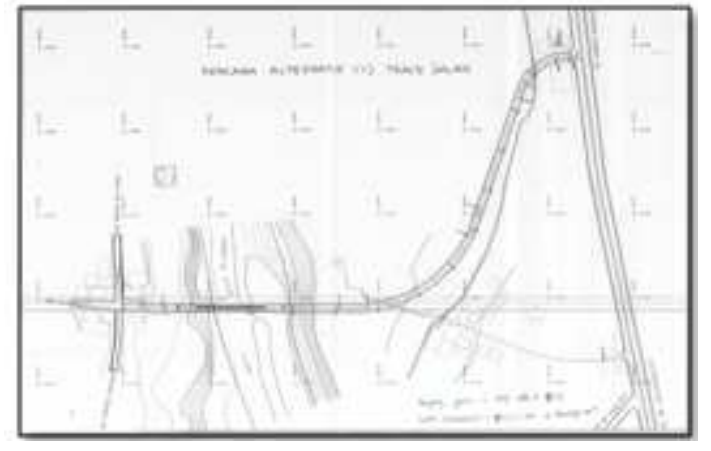

Gambar 1. Situasi Jembatan Kuranji-Durian Tarung

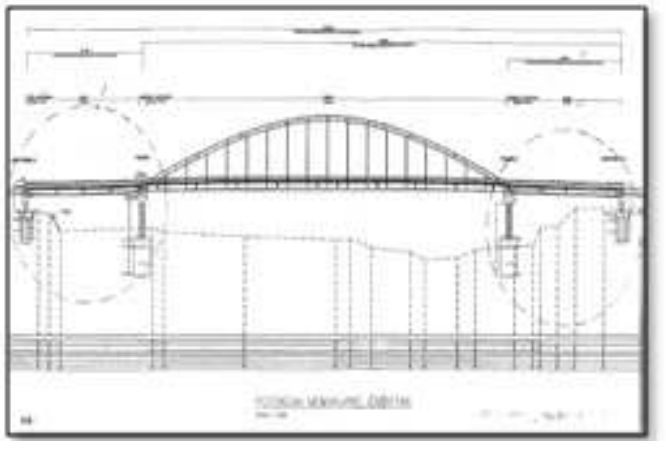

Gambar 2. Potongan Melintang Jembatan

c. Pelaksanaan konstruksi dan permasalahannya.

Pada tahun 2010 sampai dengan 2012 dilaksanakan 2 kepala jembatan (abutmen), pilar di kanan aliran Batang Kuranji dan pengadaan balok girder jembatan untuk bagian kanan aliran pada arah Kelurahan Kuranji. Pada tahun 2012 sampai dengan 2014 dilaksanakan pilar jembatan di kiri aliran, pengadaan balok girder jembatan untuk bagian kiri aliran Batang Kuranji, pemasangan balok girder serta lantai jembatan di kedua bentang jembatan pada arah Kelurahan Ambacang dan Kelurahan Kuranji..

Pada tahun 2014 jembatan di bagian tengah (konstruksi rangka baja) belum dilaksanakan, karena oprit dan jalan penghubung jembatan di kanan aliran Batang Kuranji lahannya belum bebas. Penggunaan lahan untuk oprit dan penghubung jembatan seluas $4.075 \mathrm{~m} 2$, mencakup di Kelurahan Kuranji di kanan aliran Batang Kuranji seluas $2.851 \mathrm{~m} 2$ dan di Kelurahan Pasar Ambacang di kiri aliran Batang Kuranji seluas $1.224 \mathrm{~m} 2$. Diantara tiga bidang tanah di Kelurahan Kuranji terdapat sebidang tanah dan bangunan seluas $2.088 \mathrm{~m} 2$ belum bebas karena pemilik tanah meminta nilai ganti rugi jauh diatas ketetapan Walikota Padang, yaitu sebesar Rp. 450.000/m2 (Gambar 3). Hal ini bisa dimaklumi, karena pemilik tanah memperkirakan harga tanah setelah proyek selesai dan jalan telah difungsikan. Proses ganti rugi tanah ini sudah dilaksanakan sejak 17 April 2011 sampai dengan sekarang, tetapi masih belum membuahkan hasil. 


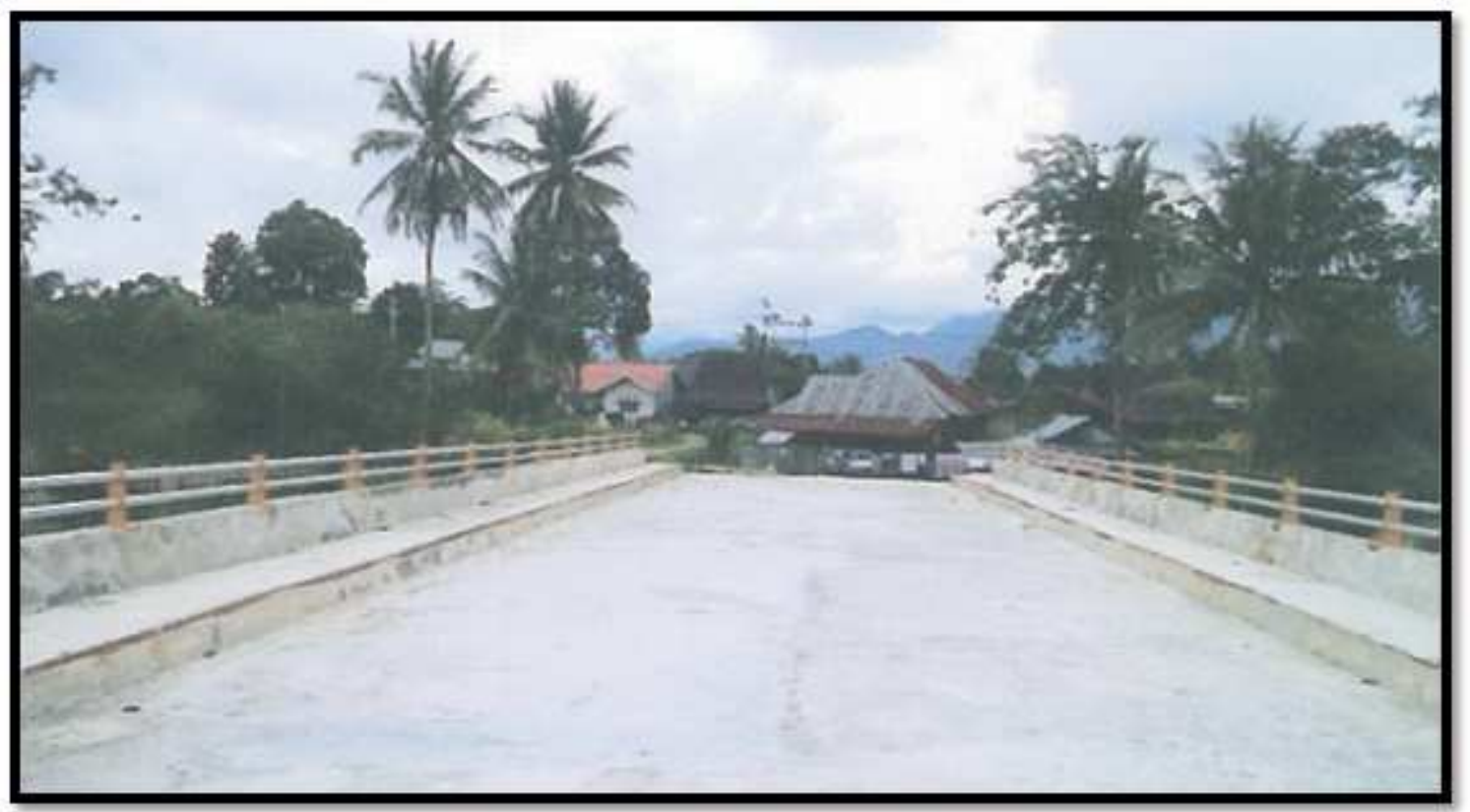

Gambar 3. Rumah dan Tanah yang Belum Bebas di Kanan Aliran Batang Kuranji

\subsection{Pembangunan bendung dan saluran irigasi Sawah Laweh Tarusan di Kabupaten Pesisir} Selatan.

a. Irigasi Sawah Laweh Tarusan dibangun pada tahun 1980-an dengan sistem pompa untuk mengairi lahan sawah 3.200 hektar. Beberapa tahun ini sistem irigasi pompa mengalami kendala antara lain besarnya biaya operasi dan pemeliharaannya termasuk besarnya sedimentasi sungai.

b. Pemerintah dengan kesepakatan masyarakat petani akan melaksanakan penggantian irigasi sistem pompa dengan sistem gravitasi dengan membangun bendung dan saluran irigasinya. Untuk dapat mengairi sawah petani dimaksud lokasi bendung direncanakan dibangun 9,76 km di hulu lokasi pompa (Gambar 4).

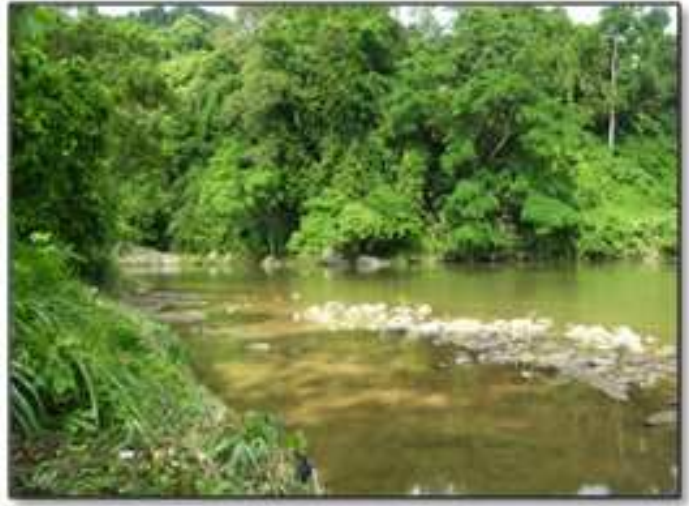

Gambar 4. Lokasi Rencana Bendung

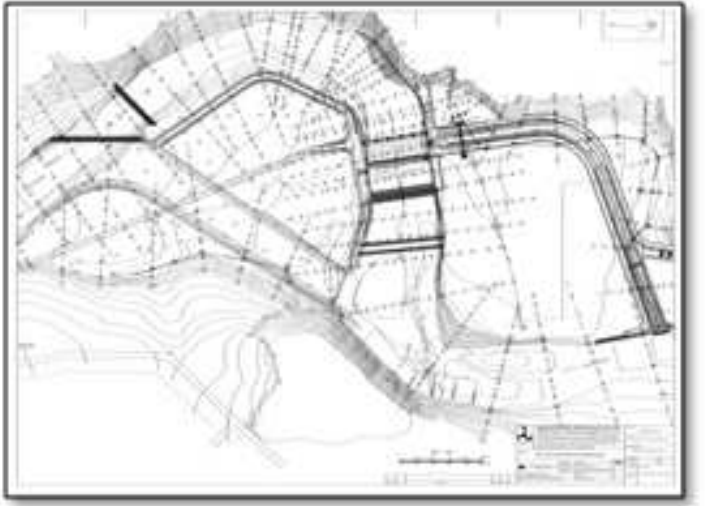

Gambar 5. Situasi Rencana Bendung

a. Data teknis jaringan irigasi. Data kontrak antara Pejabat Pembuat Komitmen Kementerian Pekerjaan Umum dengan Kontraktor PT. Adhi Karya tanggal 18 Desember 2013, sepakat untuk membangun sebuah bendung lebar 75 meter (Gambar 5), sebuah jembatan 
penyeberangan 75 meter, saluran induk 9.761 meter, saluran sekunder 11.000 meter, bangunan talang 3 unit dan bangunan bagi/sadap 82 unit. Waktu pelaksanaan konstruksi 1.440 hari mulai tanggal 18 Desember 2013.

b. Pelaksanaan konstruksi dan permasalahannya. Selama 8 bulan sejak kontrak ditanda tangani oleh Pejabat Pembuat Komitmen Kementerian Pekerjaan Umum dengan PT. Adhi Karya belum dapat dimulai pelaksanaanya karena lahan belum bebas. Mulai bulan September 2014 pekerjaan konstruksi bendung sudah dapat dikerjakan, sedangkan untuk pekerjaan saluran dan bangunan masih dalam proses musyawarah mengenai besarnya ganti rugi tanah dan tanaman. Harga yang diminta oleh masyarakat sangat tinggi. Masyarakat berpedoman kepada harga tanah yang pernah diganti rugi oleh PT. PLN. Pemberian ganti rugi dengan harga tinggi oleh PT. PLN mungkin bisa terjadi karena luas tanah yang dibayar ganti ruginya kecil. Sedangkan luasan tanah untuk bendung dan saluran irigasi, luas yang harus diganti rugi sangat besar.

\subsection{Pembangunan Saluran Irigasi Batang Anai di Kabupaten Padang Pariaman dan Kota Pariaman.}

a. Bendung dan jaringan irigasi Batang Anai mulai dibangun tahun 1994 dan direncanakan untuk mengairi lahan sawah seluas 13.600 hektar. Saat ini sebagian sawah sudah mendapat air irigasi (Gambar 6 dan 7)

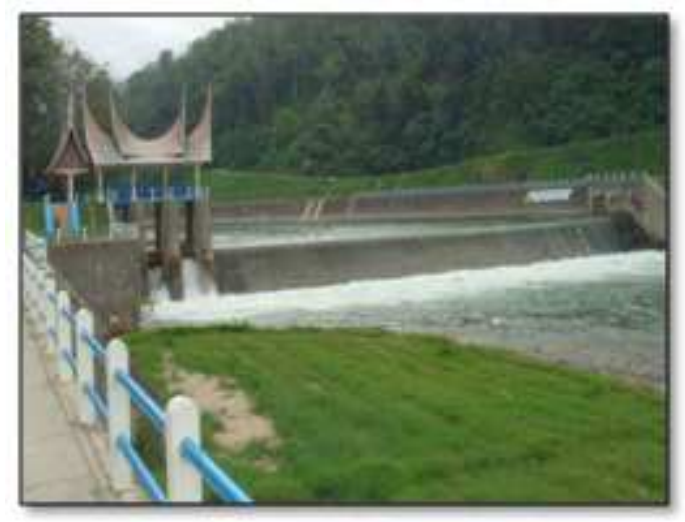

Gambar 6. Bendung di Lubuk Simantung

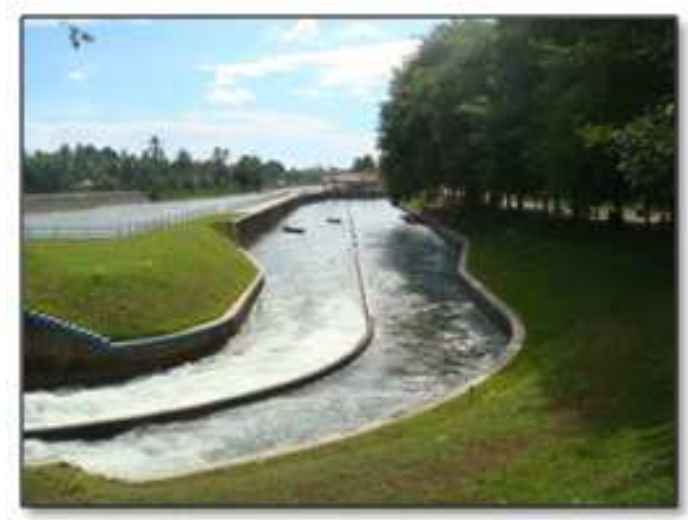

Gambar 7. Saluran Induk untuk 13.600 hektar

b. Data teknis jaringan irigasi. Pada jaringan irigasi terdapat sebuah bendung dengan lebar $100 \mathrm{~m}$, saluran induk $34.750 \mathrm{~m}$, saluran sekunder $162.600 \mathrm{~m}$, bangunan bagi sadap 174 unit dan bangunan pelengkap lainnya sejumlah 274 unit. Saat ini sedang dilaksanakan saluran, bangunan bagi sadap dan bangunan pelengkap untuk mengairi sawah tadah hujan seluas 2.300 hektar (1.500 hektar terletak di Kabupaten Padang Pariaman dan 800 hektar di Kota Pariaman), dilaksanakan oleh PT. Hutama Karya dan direncanakan selesai pekerjaan konstruksinya pada akhir Desember 2015.

c. Pelaksanaan konstruksi dan permasalahannya. Pada pekerjaan konstruksi yang sedang dilaksanakan oleh kontraktor PT. Hutama Karya terdapat pekerjaan saluran yang belum dapat dilaksanakan sepanjang 4.000 m (luas tanah 4.000 m x 20 m) di Kenegarian Kurai Taji Kecamatan Nan Sebaris Kabupaten Padang Pariaman (Gambar 8). Lahan tersebut sudah dibebaskan dengan ganti rugi pada tahun 2008 berdasarkan SK. Bupati Padang Pariaman tahun 2005. Akan tetapi, saat pekerjaan akan dilaksanakan tahun 2014 pemilik lahan tidak mengijinkan pelaksanaan pekerjaan untuk membuat saluran irigasi pada lokasi tersebut karena menuntut nilai ganti rugi sesuai dengan nilai ganti rugi yang berlaku saat ini (SK. Bupati Padang Pariaman tahun 2011). Di lain pihak, pihak Pemerintah tidak 
mempunyai dasar hukum menambah ganti rugi karena tanah tersebut sudah dibayar sebelumnya. Pada saat ini, kasus ini sudah ditangani oleh pihak Kepolisian.

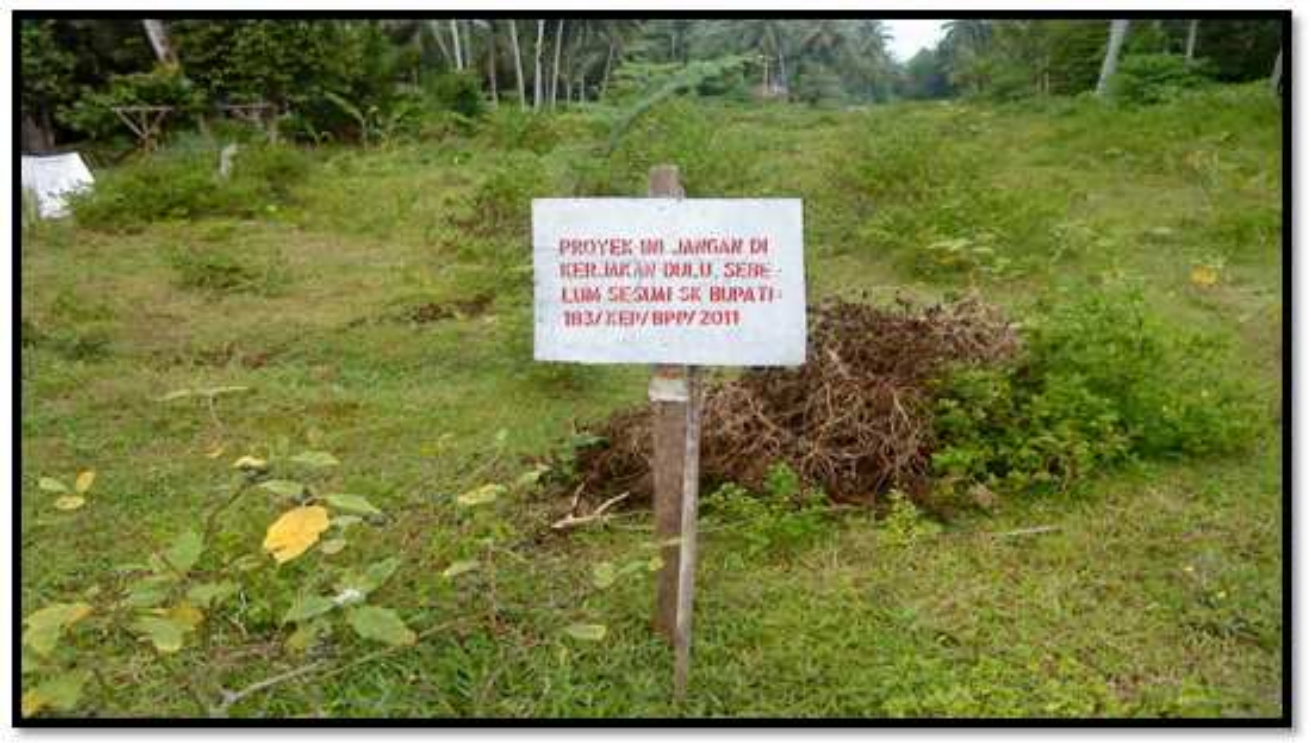

Gambar 8. Rencana Saluran di Kenagarian Kurai Taji yang Belum Bisa Dikerjakan

\subsection{Pembangunan Peningkatan Jalan Masuk ke Tempat Pembuangan Akhir Sampah di Kota Payakumbuh.}

a. Data teknis jalan. Pekerjaan peningkatan jalan masuk dengan perkerasan ke Tempat Pembuangan Akhir Regional di kawasan Taratak Padang Karambia sepanjang 2 km, lebar jalan $7 \mathrm{~m}$ dan tanah yang akan dipakai dengan lebar $12 \mathrm{~m}$, dilaksanakan oleh CV. Sarana Konstruksi dengan dana APBD tahun 2014 Dinas Prasarana Jalan, Tata Ruang dan Permukiman Provinsi Sumatera Barat.

b. Pelaksanaan konstruksi dan permasalahannya. Sepanjang jalan tersebut terdapat 10 bidang tanah yang akan terkena tapak jalan dan drainasenya. Didalamnya terdapat sebidang lahan seluas $1.128 \mathrm{~m} 2$ yang masih bermasalah. Pada awalnya, wakil keluarga pemilik lahan ini sudah setuju bersama 9 pemilik lahan lainnya dengan harga yang ditawarkan Pemerintah. Akan tetapi, pada saat akan dilakukan pembayaran terjadi permasalahan karena salah satu anggota keluarga tidak setuju dengan harga yang telah disepakatioleh wakil keluarga tersebut. Oleh karena itu, Panitia Pembebasan Tanah Kota menitipkan dananya ke Pengadilan Negeri sesuai peraturan perundang-undangan (Koran Padang Eksprestanggal 17dan 19 September 2014).

Selain itu pada lokasi ini juga terjadi perbedaan pandangan dalam perhitungan luas tanah. Pemerintah menetapkan luasan tanah berdasarkan sipat datar saja (luasan secara horisontal), sedangkan masyarakat menuntut luasan tanah sesuai dengan kemiringannya. Hal ini terjadi karena kurangnya sosialisasi dari panitia pembebasan lahan kepada masyarakat. Sampai saat ini, musyawarah diantara keluarga pemilik tanah yang belum menerima ganti rugi, Pemerintah Kota Payakumbuh dan Dinas Prasarana Jalan, Tata Ruang dan Permukiman masih dalam proses.

\subsection{Permasalahan dalam pengadaan lahan.}

Dari uraian permasalahan di empat lokasi proyek studi kasus di atas, dapat dirangkum beberapa permasalahan yang biasa terjadi dalam proses pengadaan lahan bagi pembangunan untuk kepentingan umum, antara lain : 
a. Sosialisasi lokasi lahan yang akan terkena tapak bangunan yang tidak optimal, bisa karena desain konstruksi yang tidak mantap, adanya lahan tanah miring/tidak datar.

b. Nilai apraisal tanah kemungkinan hanya mempertimbangkan harga tanah saat penilaian, belum mencerminkan harga tanah setelah infrastuktur selesai dilaksanakan.

c. Pelaksanaan musyawarah yang berlarut-larut karena nilai apraisal tidak diterima masyarakat.

d. Masyarakat berharap nilai ganti kerugian yang terlalu tinggi dari nilai apraisal dan NJOP.

e. Masyarakat tidak melepaskan lahannya dimungkinkan karena pekerjaan konstruksi tertunda pendanaan ataupun lamanya proses balik nama sertifikat.

\section{KESIMPULAN DAN SARAN}

Kesimpulan dan saran yang dapat disampaikan dari penelitian ini adalah:

a. Pengadaan tanah pembangunan untuk kepentingan umum banyak dilakukan melalui pemberian ganti rugi tanah, bangunan dan tanamannya, mekanismenya diatur dalam Undangundang No. 2 tahun 2012 dan Peraturan Presiden No. 71 tahun 2012.

b. Sebagian besar permasalahan tanah yang terjadi adalah tidak tercapainya kesepakatan harga antara pemilik tanah dan Pemerintah, dimana Pemerintah mengacu kepada NJOP dan nilai apraisal harga tanah.

c. Peraturan pengadaan tanah untuk kepentingan umum tahun 2012 belum dapat sepenuhnya menyelesaikan dan menuntaskan permasalahan dilapangan.

d. Dalam membuat nilai apraisal tanah oleh tim independen, disarankan harga tanah tidak hanya mempertimbangkan harga saat ini tetapi juga harga saat pembangunan selesai dan dimanfaatkan

\section{DAFTAR KEPUSTAKAAN}

Kontrak No. KU 0808/10/BWS.SV-PJPA/IRA-II/XII/2013 tanggal 18 Desember 2013

Keputusan Presiden No. 55 Tahun 1993 tentang Pengadaan tanah bagi pelaksanaan pembangunan untuk kepentingan umum

Undang-undang No. 2 tahun 2012 tentang Pengadaan tanah bagi pembangunan untuk kepentingan umum

Peraturan Presiden No. 71 tahun 2012 tentang Penyelenggaraan pengadaan tanah dalam pembangunan untuk kepentingan umum

Peraturan Presiden No. 76 tahun 2006 tentang Perubahan atas Peraturan Presiden No. 36 tahun 2005 tentang Pengadaan tanah dalam pelaksanaan pembangunan untuk kepentingan umum.

Koran Padang Ekspres tanggal 17 September 2014 halaman 13, judul Warga Tuntut Ganti Rugi TPA Sampah dan tanggal 19 September 2014 halaman 13, judul Ganti Rugi Tanah TPA BelumTuntas 